\title{
Layout Effect of Manufacturing Workplace to Illumination of Working Position
}

\author{
Darina Dupláková*», Marián Flimel*
}

\begin{abstract}
*Department of Manufacturing Management, Faculty of Manufacturing Technologies with a seat in Presov, Technical University of Kosice, Bayerova 1, 08001 Presov, Slovakia

(darina.duplakova@tuke.sk)
\end{abstract}

\begin{abstract}
$\$$ Technical University of Kosice, Faculty of Manufacturing Technologies with a seat in Presov, Bayerova 1, 08001 Presov, Slovakia, Tel: 004210556026402, darina.duplakova@tuke.sk
\end{abstract}

Received: 28.02.2017 Accepted: 03.03.2017

\begin{abstract}
Layout of manufacturing workplace is demanding process which has to take into consideration the technical knowledge, ergonomic rules and factors. One of these factors is illumination, too. The optimization of working position illumination is significant element of working environment and it has strong effect on safety at the work, well-being, health, motivation and performance of workers. Presented article is focused on effect consideration of layout and operational layout of workplace to illumination of working position by software modelling in the stage of workplace design.
\end{abstract}

Keywords Layout, Illumination, Dialux, Manufacturing workplace.

\section{Introduction}

At the present time it is one of issues the method of machines and devices layout during the design of manufacturing workplaces. Designers and managers have to observe the standards so that the layout met the demanding criterions. Studies have established that natural lighting is more conducive to a productive and healthy working environment than is artificial lighting. [1] From the point of view of acceptable light climate provision at the workplace, it is necessary to comprehensive perspective on solution of illumination system for day, artificial or compound illumination. From the evaluated 12 criterions of illumination: intensity, evenness, directivity, shadiness, glare, colour, safety, aesthetics, economy, environmental friendliness, maintenance and flexibility, subject of this article is the evaluation of illumination intensity $\mathrm{E}_{\mathrm{m}}[\mathrm{lx}]$ for artificial illumination and daylight factor D [\%] for day illumination. The development of modern computing technology has provided a strong means of analysing the mathematical models of metallurgical processes. [2] The suitability of illumination for various variants of layout will be declared by application of simulation software Dialux and Wdls 4.1.

\section{Methodical procedure of illumination system suggestion in relation to layout}

In the manufacturing halls, the illumination of workplaces is conditioned by various factors [3]: a) shape of hall, reflectance of surfaces,

b) size and placement of transparent constructions,

c) kind, power and arrangement of lights, height of light above the work surface,

d) type of manufacturing has effect on layout in relation to material flows, maintenance, etc.,

e) operation

At the design stage of workplace by software modelling, it is suitable to observe the following methodical procedure:

1) assignment of geometrical characteristics and features of space

2) to determine the necessary machines and devices (sizes) according to manufacturing requirements

3) to compile the possible alternatives of layout

4) to suggest the alternatives of artificial illumination (e.g. by Dialux)

5) to select the suitable alternatives of layout in relation to the achievement of required intensity of working position illumination

6) to model the day illumination for selected alternatives with the suggestion variation of transparent constructions

7) to select of optimal solution (alternative) and its finishing by final model of artificial illumination 
This presented methodical procedure is suitable for sort of manufacturing when there is not frequent transfer of machines (e.g. piece production). The presented procedure was verified in example of manufacturing hall with fixed position of 5-axis CNC machine (DMU 340P) with variableness possibility of four other machines.

\section{Solved example of illuminating system of manufacturing hall}

According to point No. 1, 2 and 3 it was suggested the $(4 !)=24$ alternatives of machine arrangement for concrete conditions. Individual arrangements are presented in the following figure.

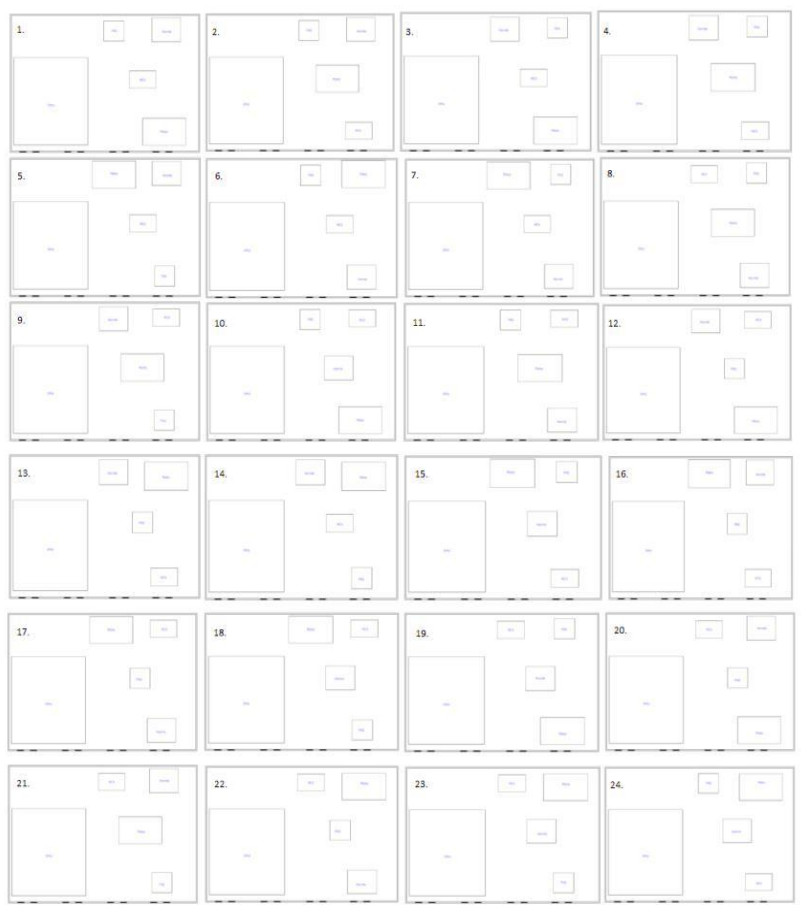

Fig. 1. Arrangement variants of manufacturing workplace.

It was assigned the input data to the software Dialux on the basis of the fourth point of methodical procedure and the results are presented in the following table. The requirements were evaluated on the basis of STN EN $12464-1$. [4] This standard was written by Work Group 2 of the Technical Committee TC 169 of the European Committee for Standardisation (CEN). The standard governs indoor workplace lighting. As with most standards, minimum requirements are laid down. In other words, it concerns a minimum that workplace lighting and the direct environment needs to meet. EN 12464-1 is an application standard. In this document the standard is described with a view to developing a lighting solution:

- gathering the necessary project data and laying down the preconditions;

- considering different alternatives (determining the most suitable lighting concept, choice of luminary type, choice of lamp, ...);

- calculating and documenting
Table 1. Results - average values of illumination (AVI) in lux (at the work surface $0.85 \mathrm{~m}$ near machines)

\begin{tabular}{|c|c|c|c|c|c|c|}
\hline Option & $\begin{array}{c}\text { AVI } \\
\text { of } \\
\text { hall }\end{array}$ & $\begin{array}{c}\text { AVI of } \\
\text { FNG } \\
\text { machine }\end{array}$ & $\begin{array}{c}\text { AVI } \\
\text { of } \\
\text { Hermle } \\
\text { machine }\end{array}$ & $\begin{array}{c}\text { AVI } \\
\text { of } \\
\text { MCV } \\
\text { machine }\end{array}$ & $\begin{array}{c}\text { AVI } \\
\text { of } \\
\text { Matec } \\
\text { machine }\end{array}$ & $\begin{array}{c}\begin{array}{c}\text { Satisfaction } \\
\text { of } \\
\text { requirements } \\
\text { STN EN }\end{array} \\
12464-1[4]\end{array}$ \\
\hline 1. & 312 & 530 & 424 & 473 & 426 & not comply \\
\hline 2. & 300 & 471 & 331 & 459 & 416 & not comply \\
\hline 3. & 311 & 487 & 459 & 473 & 426 & comply \\
\hline 4. & 299 & 394 & 391 & 458 & 416 & not comply \\
\hline 5. & 308 & 501 & 416 & 465 & 427 & not comply \\
\hline 6. & 311 & 529 & 458 & 469 & 394 & not comply \\
\hline 7. & 309 & 481 & 452 & 469 & 431 & comply \\
\hline 8. & 301 & 396 & 455 & 423 & 418 & not comply \\
\hline 9. & 299 & 491 & 390 & 357 & 417 & not comply \\
\hline 10. & 310 & 523 & 433 & 438 & 424 & not comply \\
\hline 11. & 301 & 469 & 444 & 358 & 418 & not comply \\
\hline 12. & 313 & 509 & 468 & 456 & 444 & not comply \\
\hline 13. & 310 & 503 & 461 & 488 & 396 & not comply \\
\hline 14. & 309 & 503 & 456 & 467 & 386 & not comply \\
\hline 15. & 305 & 469 & 447 & 462 & 422 & not comply \\
\hline 16. & 309 & 501 & 425 & 485 & 434 & not comply \\
\hline 17. & 309 & 501 & 469 & 451 & 436 & not comply \\
\hline 18. & 305 & 499 & 446 & 429 & 420 & not comply \\
\hline 19. & 310 & 476 & 451 & 479 & 437 & comply \\
\hline 20. & 313 & 509 & 432 & 494 & 445 & not comply \\
\hline 21. & 299 & 491 & 330 & 424 & 416 & not comply \\
\hline 22. & 312 & 504 & 451 & 495 & 399 & not comply \\
\hline 23. & 307 & 499 & 446 & 481 & 372 & not comply \\
\hline 24. & 307 & 520 & 446 & 465 & 377 & not comply \\
\hline
\end{tabular}

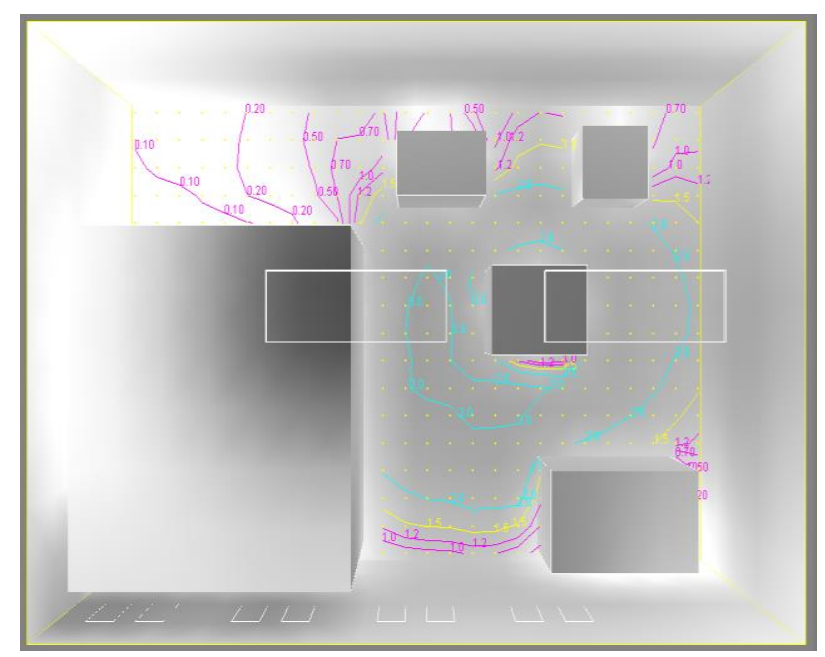

Fig. 2. Course of daylight factor (isophote $\mathrm{D}=1.5 \%$ ) [5] final solution - layout No 19.

After the evaluation (point No. 5) was suitable the tree alternatives No. 3, 7 and 19 which was evaluated according to point No. 6. It was calculated the daylight factors of illumination suitable alternatives by simulation software Wlds 4.1. Then it was evaluate the alternative with the most advantageous ratio of suitable day illumination surface (Point No. 7). In Figure 2 and Figure 3 there are the graphical outputs of layout optimal solution for alternative No. 19. 


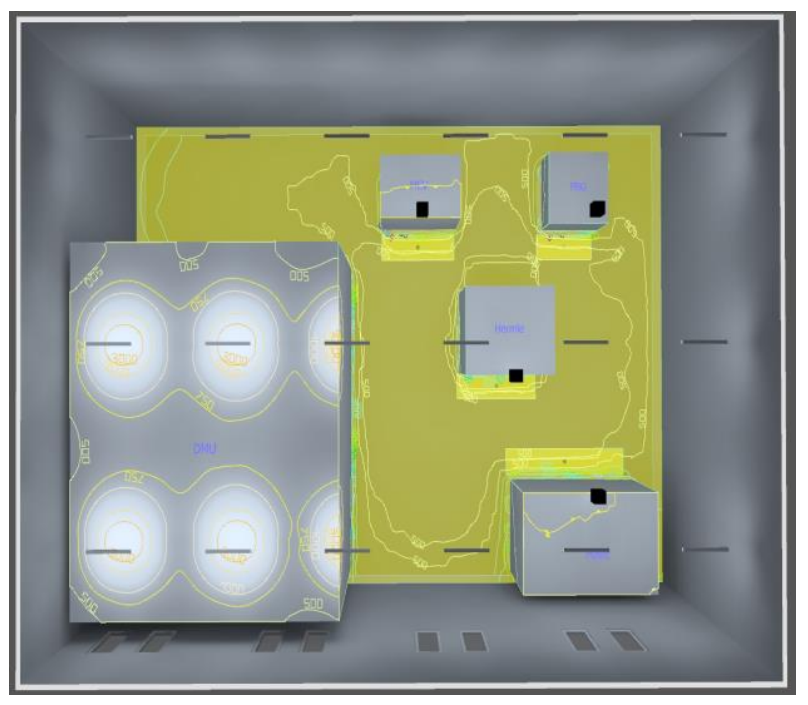

Fig. 3. Course of isophote $\mathrm{Em}=300 \mathrm{~lx}$ - layout No. 19 .

It was established that given hall is not suitable for day illumination because current side lighting or with the required $1 / 3$ of the acceptable day illumination. From this reason it was suggested two upper skylights (sizes 6 × $2 \mathrm{~m}$ ) and these skylights ensure the required values at the working zones around the machines. The artificial illumination it will be suitable in realization: 24 lights, $4 \times 80 \mathrm{~W}$ power, $7 \mathrm{~m}$ height.

\section{Conclusion}

One of the most widely use fields of electricity is lighting. [6] A lots of simulation software are used for various fields of manufacturing. [7] Model solutions of workplaces illumination are significant tool for optimization of workplace layout. The presented methodical procedure is only the solution fragment of comprehensive optimization of workplace design when it will be necessary to allow for other relevant factors of the environment and working activities.

\section{References}

[1] T. Joseph, A. Dutta,"Estimating the annual range of global illuminance on a vertical south facing building façade", International Journal of Energy and Environment, vol. 6, no. 3, pp. 265-272, 2015.

[2] X. Shen, et al."Numerical simulation and analyses for sinter cooling process with convective and radiative heat transfer", International Journal of Energy and Environment, vol. 7, no. 4, pp. 303-316, 2016.

[3] M. Flimel, "Možnosti optimalizácie denného osvetlenia na výrobných pracoviskách", Zborník zo seminára Slovalux 2015 [online]. Bratislava: Slovenská svetelnotechnická spoločnost', 2015.

[4] STN EN 12464-1:2012 Light and lighting - Lighting of work places - Part 1: Indoor work places.

[5] Vyhláška 541/2007 $\quad$ Z.z. o podrobnostiach a požiadavkách na osvetlenie pri práci, 2007.

[6] I. Aliskan, R. Keskin, "Fluorescent Lamp Modelling and Electronic Ballast Design by the Support of Root Placement, International journal of engineering technologies, vol. 2, no. 3, pp. 118-123, 2016.

[7] L. Knapčíková, "Using of simulation software in the field of reverse logistics" Trendy V podnikání 2012 : mezinárodní vědecká konference : 15. - 16.11.2012, Plzeň. - Plzeň : Západočeská univerzita, pp. 1-5, 2012. 